\title{
The possibilities of using DME (BioDME), as an additive to conventional gaseous fuels in SI engine
}

The results of SI engine fueled with blends of LPG and DME are presented in the paper. The range studies submitted includes measurements at varying engine loads, at selected values of speed. The research was conducted on a chassis dynamometer, specifying the engine load by the degree of throttle opening. Value of the mass fraction of DME in the blend with LPG was determined based on previous analyzes. The selected fuel blends containing from 7 to 17\% DME (mass fraction). During the study was also performed a series of comparative measurements with pure LPG. Analyses show that of DME can be used as a partial substitute for LPG in SI engines. Its presence does not a negative impact on performance and emissions of the engine. The obtained results indicate that the amount of addition of DME should be varied depending on the engine load. Moreover, the use of this fuel does not require changes to the design fueling system and storage of $L P G$.

Key words: dimethyl ether, DME+LPG, fuel blend, SI engine

\section{Introduction}

The use of DME as fuel also in SI engines is becoming more frequently considered. Economic and ecological benefits combined with very favorable physicochemical properties are the direct cause of these interests $[5,6]$. The most important aspect to mention is the possibility of obtaining DME as a renewable fuel produced from biomass. As a result, there is the possibility of significant reduction of $\mathrm{CO}_{2}$ emissions, compared with LPG, 30-80\% [1] and $\mathrm{NO}_{\mathrm{x}}$ reduction: $5-15 \%$ [1], in the total balance. On the other hand, similar LPG properties allow to use the infrastructure and fueling systems commonly used for LPG.

Among the methods of obtaining DME on an industrial scale, the most effective are gas-based technologies (e.g. the formation of DME from synthesis gas). DME is characterized by a high $\mathrm{CN}$, of over 55 (for a comparison diesel has about 53), which can also be used in CI engines. In SI engines is used in combination with LPG [7, 8]. In the previous studies, carried out at the Faculty of Transport of Silesian University of Technology [2, 3], the changes that occur in the combustion process, depending on the amount of DME's participation, were determined. These tests were conducted at idle and at full engine load for selected speeds. In those preliminary studies, the range of changes in participation of DME in the blend with LPG, which ensures proper combustion process has been determined. The results showed that a limited DME additive, in the range of approximately $7-15 \%$ by weight, increased engine performance. On the other hand, increasing the DME's share over this gives the opposite effect (Fig. 1). These conclusions were formulated on the basis of the results obtained at full engine load (full throttle opening). Interpretation of these changes is the result of the analysis of the function of the heat release rate during the combustion process (Fig. 2). Too large amount of DME in the fuel causes a reduction in combustion rate and prolongs the process. The engine management during the test was performed according to the settings developed by the manufacturer.

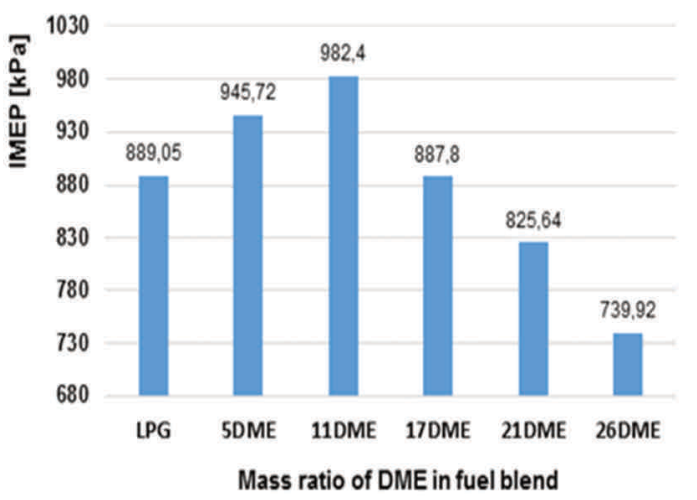

Fig. 1. IMEP for engine fueled by LPG-DME mixtures, at $2500 \mathrm{rpm}$; WOT and $\lambda=1.0$ [2]

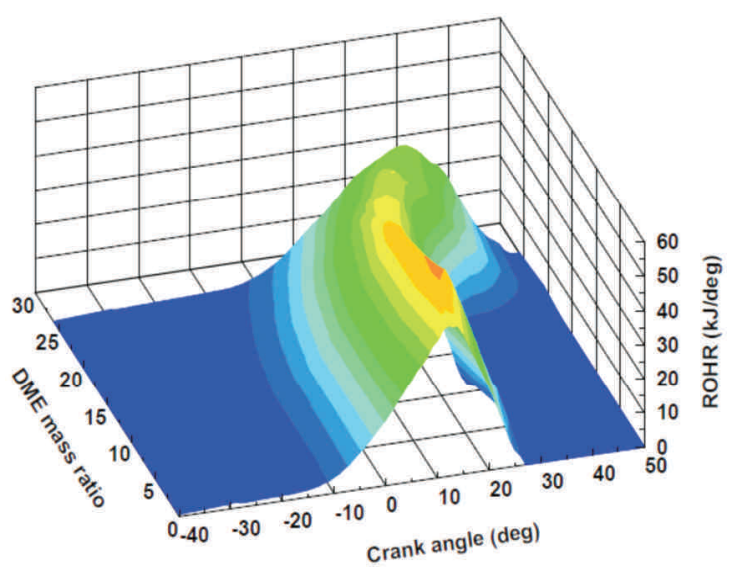

Fig. 2. ROHR as a function of DME ratio, at $2500 \mathrm{rpm}$; WOT and $\lambda=1.0[3]$

Current research was aimed at determining the basic values of the engine's performance, depending on the load. The main objective of this study is to determine the share of LPG/DME fuel components providing the highest efficien$\mathrm{cy}$, as a function of engine load. The equivalent of the engine load in the tests is degree of throttle opening. 


\section{Research of engine partial load}

\subsection{Measurement set-up}

The popular passenger car powered by 1.6 liter engine, naturally aspirated with a compression ratio of 9.6 , port fuel injection, two valves per cylinder, flat pistons and without external EGR was used in the experiments. The experiments were performed on a BOSCH FLA 203 chassis dynamometer as presented on Fig. 3. Main features characterizing the engine installed on the tested vehicle have been listed in the Table 1. Engine performance has been estimated on the basis of acquired dynamic characteristics, defining the power on wheels in function of vehicle speed. Test stand has been equipped with various transducers and sensors allowing the identification of engine operating conditions. Basic measurements and control systems allowed continuous acquisition of engine operating conditions, through registrations of:

- in-cylinder pressures, crank angle, with the TDC identification,

- power on wheels,

- manifold pressure,

- inlet air temperature,

- exhaust gases temperature,

- fuel mass flow to the engine.

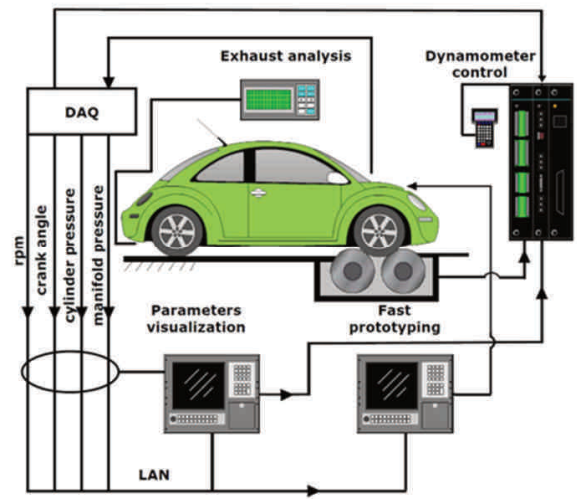

Fig. 3. Diagram of experimental stand [2]

The in-cylinder pressure was measured by Kistler 6121 piezoelectric pressure transducers and a charge amplifier, Kistler 5011A. The signals were processed in type NI PCI6143 board in a computer for online pressure measurements. The pressure recording system was also connected to the Kistler 2613B crank angle encoder giving the temporal resolution of the pressure recordings of $0.5 \mathrm{CA}$. The pressure measurements were recorded and stored on a computer, with recordings performed for 200 subsequent cycles in each test, and were further processed with the help of a script debugged in LabView 7.1 environment.
Table 1. Engine specifications

\begin{tabular}{|l|c|}
\hline Engine code & X16SZR \\
\hline Cylinder number and layout & $4 \mathrm{R}$ \\
\hline Maximum power & $55 \mathrm{~kW} @ 5200 \mathrm{rpm}$ \\
\hline Maximum torque & $128 \mathrm{~N} \cdot \mathrm{m} \mathrm{@} 9800 \mathrm{rpm}$ \\
\hline Displacement & $1598 \mathrm{ccm}$ \\
\hline Bore x stroke & $79.0 \times 81.5 \mathrm{~mm}$ \\
\hline Compression ratio & 9.6 \\
\hline
\end{tabular}

\subsection{Methodology of research}

The scope of the tests included determining the external characteristics of the engine, its maximum power and torque depending on the load. The tests were carried out according to the BOSCH FLA203 dynamometer producer's procedure, which consists in accelerating the vehicle in direct gear to the maximum engine speed and slowing down at idle speed. Taking into account the results obtained in the previous step [3], for testing were prepared 6 fuels containing: $0,7,9,11,14,17 \%$ mass DME mixed with LPG. Parameters of prepared fuels are presented in Table 2.

The test was performed for the following engine loads $21,33,48,60,75,90$ and $100 \%$. The engine load was determined based on the degree of throttle opening. Repeatable test conditions were provided by use of the accelerator pedal limiter, with different heights (Fig. 4).

Based on the experimental results, the combustion process was calculated using a verified simulation program EnComAn [4].

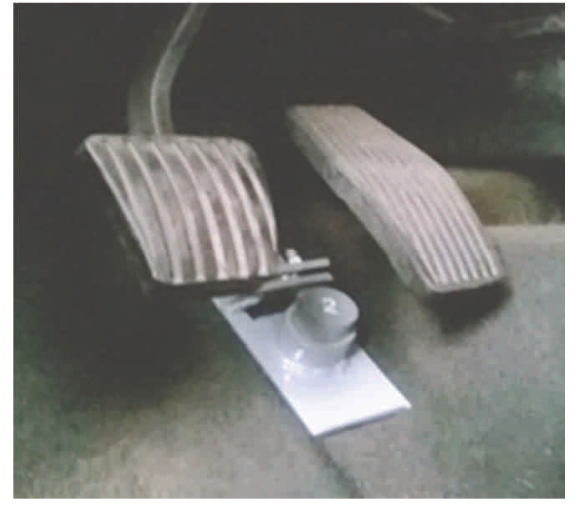

Fig. 4. View of accelerator pedal limiter

\section{Results and discussion}

\subsection{Vehicle performance}

The results of power and torque measurements of the engine in full range of speed, with constant throttle position, for one of tested fuel are shown in the graphs (Fig. 5 and 7). These results indicate that when the throttle is opened above $70 \%$, the achieved values are very close. By contrast, reducing the load below this limit reduces the value of power, torque and maximum speed.

Table 2. The parameters of fuels prepared for test

\begin{tabular}{|c|c|c|c|c|}
\hline \multicolumn{2}{|c|}{ Fuel composition $[\%$ by mass] } & $\begin{array}{c}\text { Molecular mass of fuel } \\
{[\mathrm{kg} / \mathrm{kmol}]}\end{array}$ & $\begin{array}{c}\text { Stoichiometric air fuel ratio } \\
\mathrm{A} / \mathrm{F}[\mathrm{kg} / \mathrm{kg}]\end{array}$ & Lower heating value $[\mathrm{MJ} / \mathrm{kg}]$ \\
\hline LPG & DME & 51 & 15.76 & 45.95 \\
\hline 100 & 0 & 50.615 & 15.30 & 44.67 \\
\hline 93 & 7 & 50.506 & 15.17 & 44.26 \\
\hline 91 & 9 & 50.397 & 15.04 & 43.88 \\
\hline 89 & 11 & 50.236 & 14.84 & 43.33 \\
\hline 86 & 14 & 50.080 & 14.64 & 42.78 \\
\hline
\end{tabular}




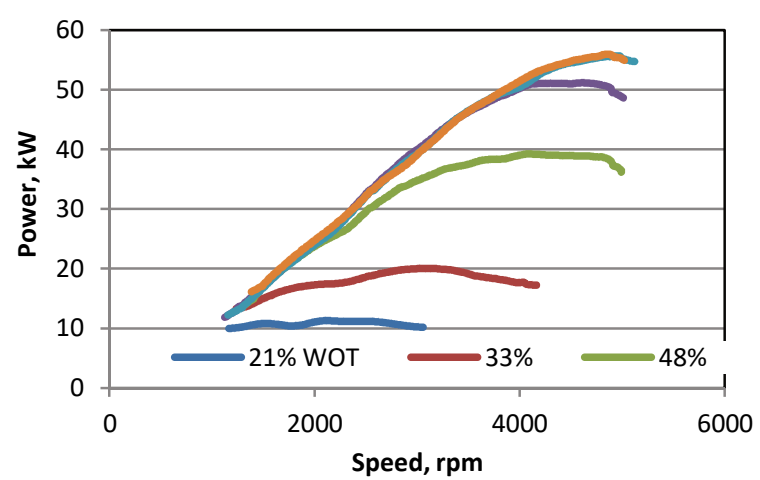

Fig. 5. Engine power for different WOT. Fuel LPG/DME: 91/9\%

The chart showing the maximum values of the measured engine power (Fig. 6) indicates that with the engine load drop, the fuel composition changes to give the maximum power (red line in the graph). The change in fuel composition consists in increasing DME's share. For the analysis of maximum torque values (Fig. 8), there is a similar tendency, although not so pronounced. The power and torque measured on the wheels of the vehicle (Fig. 9 and 10) also show that, with less engine load, an increase of the DME share has a beneficial effect to the performance of the vehicle. This area is marked on the chart.

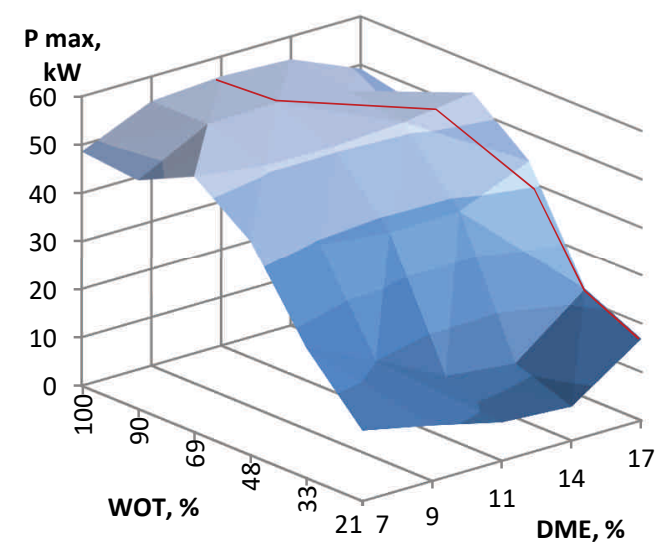

Fig. 6. Values of engine maximum power in depend of DME share \& engine load, $\lambda=1.0$

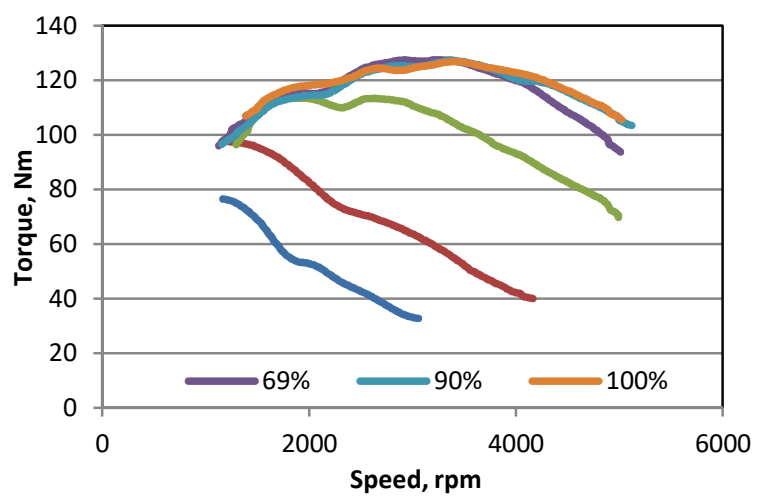

Fig. 7. Engine torque for different WOT. Fuel LPG/DME: 91/9\%

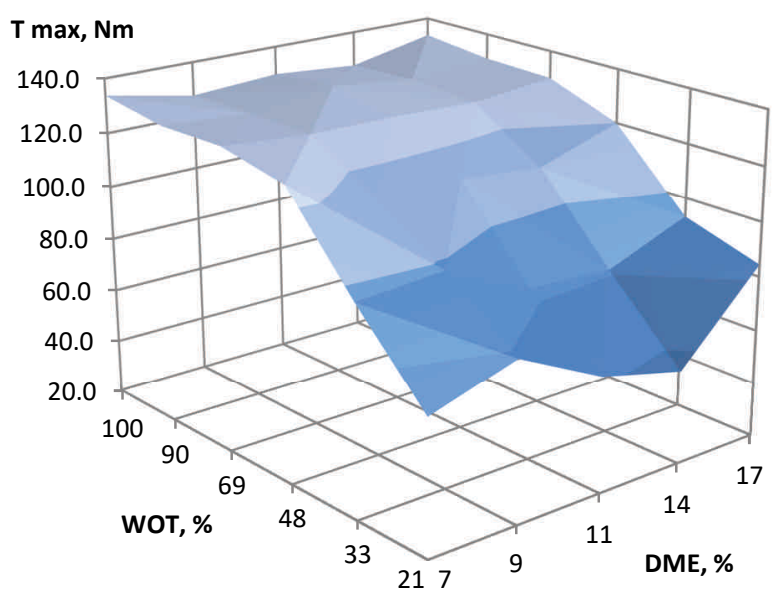

Fig. 8. Values of engine maximum torque in depend of DME share $\&$ engine load, $\lambda=1.0$

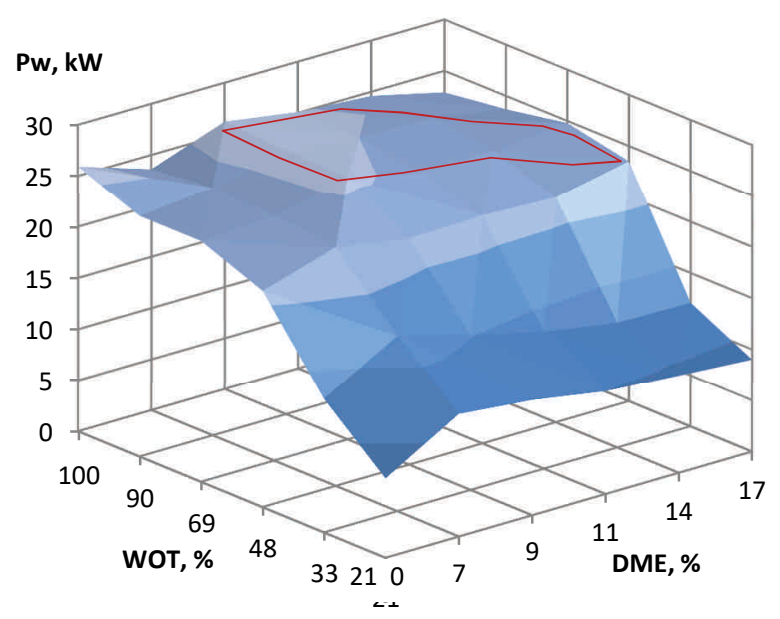

Fig. 9. The results of power on wheel measured during experimental test; $\mathrm{n}=2500 \mathrm{rpm}$

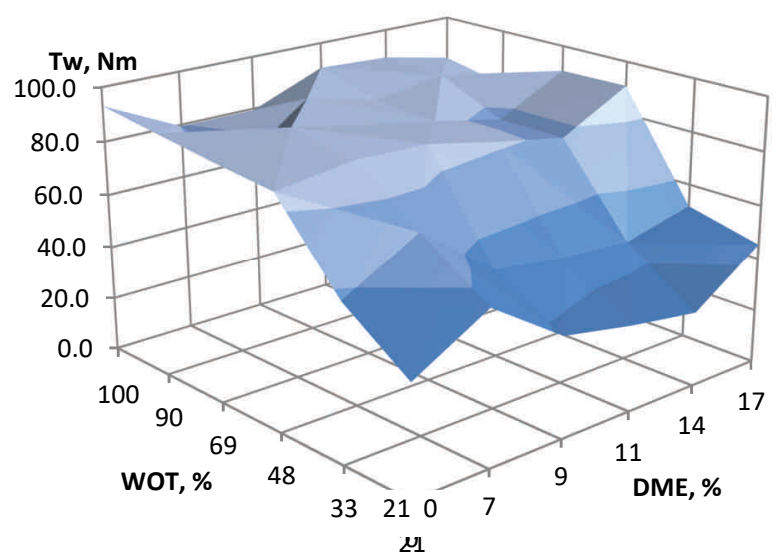

Fig. 10. The results of torque on wheel measured during experimental test; $\mathrm{n}=2500 \mathrm{rpm}$

\subsection{In-cylinder pressure and combustion process}

The observed changes are apparently evident in the analysis of the phenomena occurring in the combustion chamber. In the graph showing the maximum values of the indicated pressure (Fig. 11), it can be seen that at the full engine load the highest pressure values were obtained with 
$\mathrm{DME}=9 \%$. Increasing the share of DME reduces the value of obtained maximum pressure. On the other hand, with the reduction in engine load, the maximum pressure is observed for an ever greater share of DME.

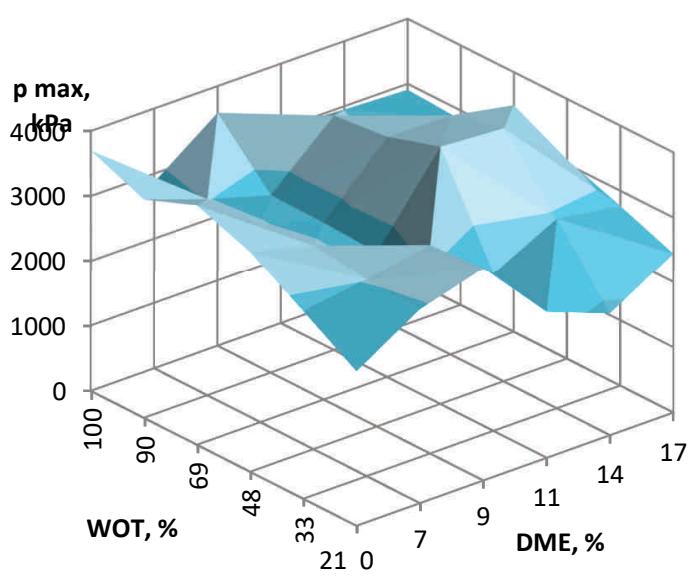

Fig. 11. Maximum in-cylinder pressure in depend of DME share \& engine load, $\mathrm{n}=2500 \mathrm{rpm}$

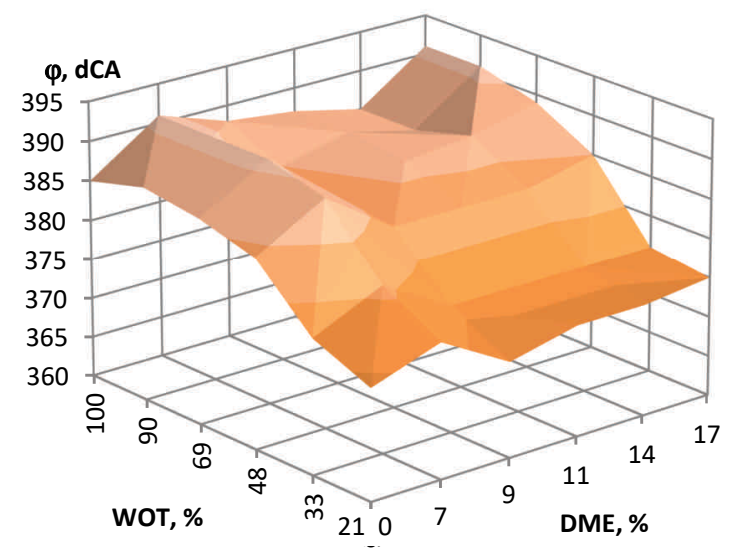

Fig. 12. A point of occurrence $\mathrm{p}_{\max }$ in working cycle, $\mathrm{n}=2500 \mathrm{rpm}$

Completion of this observation is a graph showing the angle of crank position, at which the maximum pressure is indicated (Fig. 12). The results presented on it, are information about the speed of the combustion process, among others. First of all, it is evident that a small DME addition exacerbates the course of the changes, which results in a deterioration of the engine performance parameters shown in the previous charts. In addition, there is also a delay in the occurrence of the maximum pressure point at full engine load and at several percent DME.

The following graphs (Fig. 13 and 14) show the angle of the crankshaft position corresponding to the characteristic points of the combustion process, 10 and $50 \%$ of the mass fraction burned MFB. In both cases, there is a strong relationship between the share of DME in the fuel and the rate of heat release. In the conditions which prevail in the combustion chamber at a load of $90-100 \%$, only a small addition DME allows to keep appropriate combustion velocity. Increasing DME share over $11 \%$ slows down the process under these conditions. But with decreasing engine load moves this limit, making it possible to gradually increase the addition of DME. The load change is also associated with a change in the ignition advance angle. That was determined by the original driver.

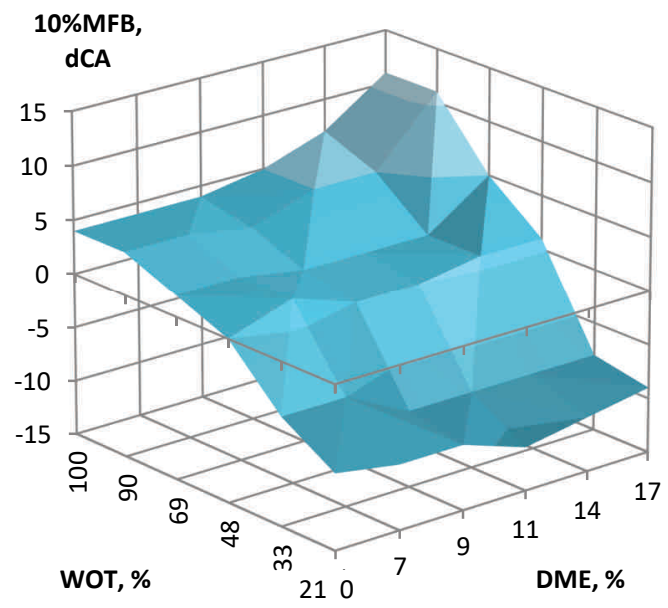

Fig. 13. A point of $10 \%$ MFB during combustion process, $n=2500 \mathrm{rpm}$

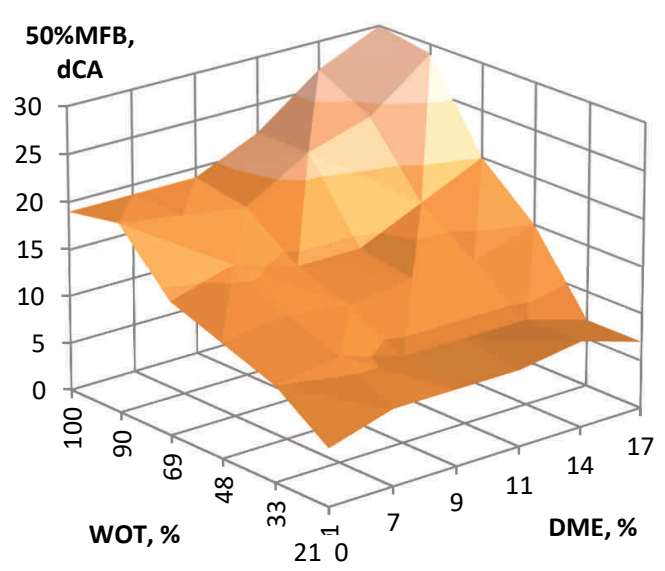

Fig. 14. A point of 50\% MFB during combustion process, $\mathrm{n}=2500 \mathrm{rpm}$

\subsection{Temperature and exhaust gas component}

The model simulation enabled the determination of temperature changes in the cylinder on the basis of experimental results. The results of the calculations are presented in graphs. Figure 15 shows the change in the maximum incylinder temperature, and Figure 16, the temperature of the exhaust gases leaving the combustion chamber. These parameters are presented in the function of the fuel composition and the load of tested engine.

In the graph of the maximum temperature can be observed that despite the drop in engine load, maximum temperature remained at a similar level to that part of the area where was tested the fuel with increased share of DME (over 11\%). In contrast, the temperature of the exhaust gas leaving the combustion chamber (the exhaust valve opening) in this area of the graph is significantly lower. The reason for these changes can be good flammability of DME (high $\mathrm{CN}$ ), which at partial load of the engine (30 to 60\% WOT) can maintain the appropriate combustion velocity. 


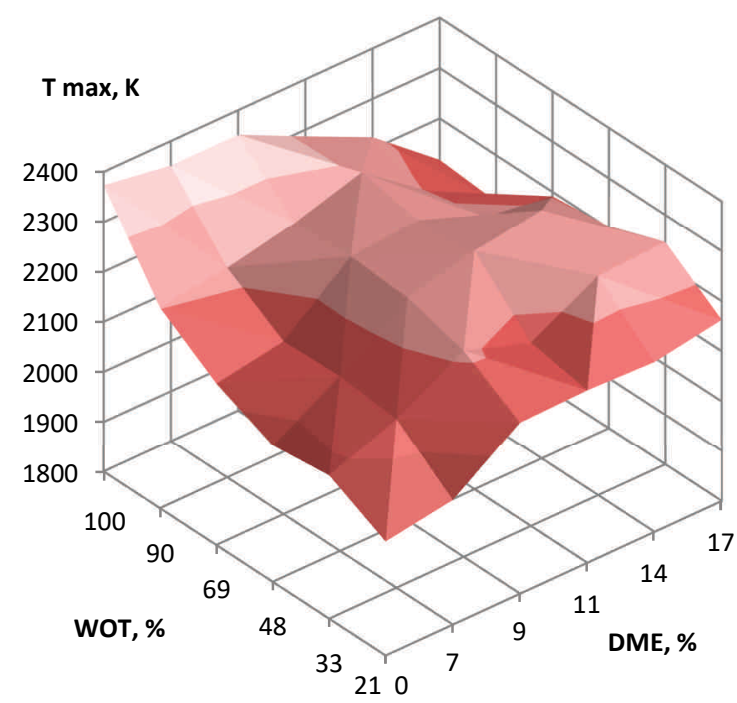

Fig. 15. Maximum in-cylinder temperature in depend of DME share \& engine load, $\mathrm{n}=2500 \mathrm{rpm}$

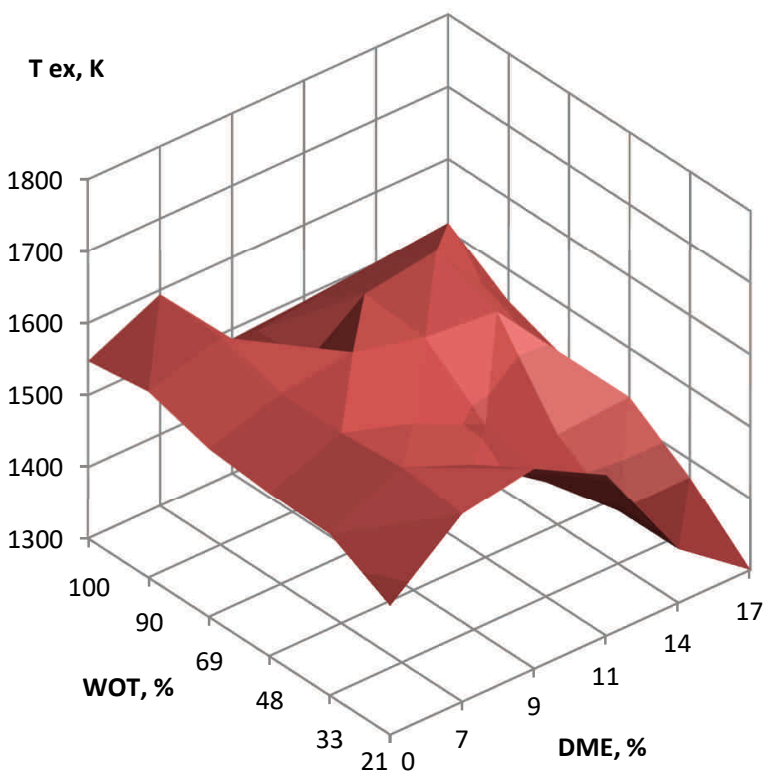

Fig. 16. An influence of DME share \& engine load on temperature of raw exhaust gases, $\mathrm{n}=2500 \mathrm{rpm}$

Another aspect of the analysis is the composition and emission of combustion products. The changes in the concentration of selected exhaust components are shown in the following graphs.

Emissions of carbon-containing compounds: $\mathrm{CO}_{2}$ (Fig. 17) and $\mathrm{CO}$ (Fig. 18) are not subject to major changes. The influence of the type of fuel is not noticeable, because in the group of the studied fuels the total share of the $\mathrm{C}$ component in the stoichiometric mixture is similar, from 2.83 to $2.86 \%$. CO emissions are maintained at a constant level of $0.045-0.035 \%$, indicating the correct course of the combustion process. The $\mathrm{NO}_{\mathrm{x}}$ concentration (Fig. 19) decreases with the decrease in engine load.

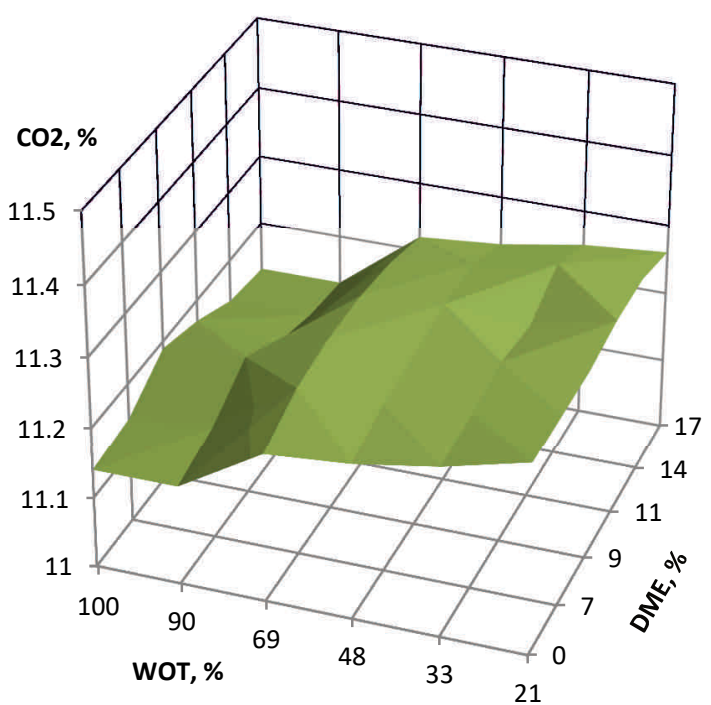

Fig. 17. An influence of DME share \& engine load on emission $\mathrm{CO}_{2}$, $\lambda=1.0, \mathrm{n}=2500 \mathrm{rpm}$

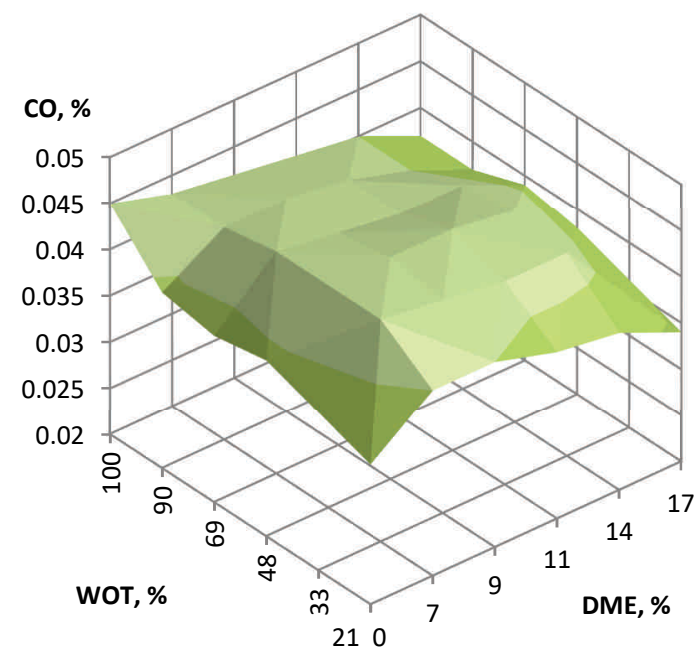

Fig. 18. An influence of DME share \& engine load on emission CO, $\lambda=1.0, \mathrm{n}=2500 \mathrm{rpm}$

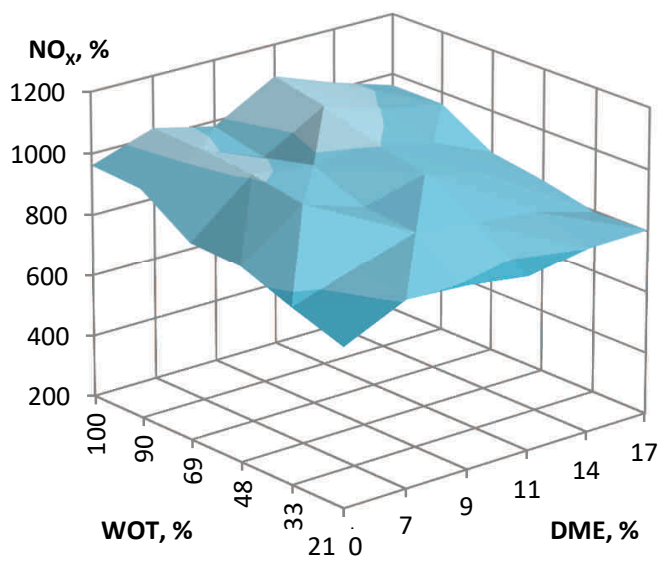

Fig. 19. An influence of DME share \& engine load on emission $\mathrm{NO}_{\mathrm{x}}$, $\lambda=1.0, \mathrm{n}=2500 \mathrm{rpm}$ 


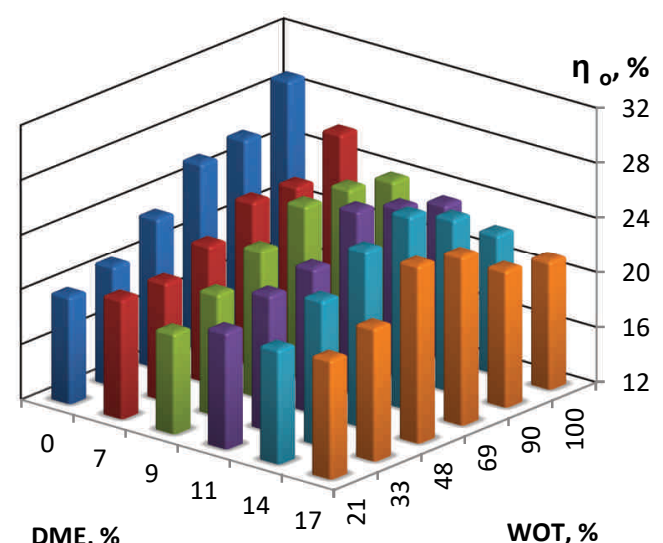

\begin{tabular}{|c|c|c|c|c|c|c|}
\hline \multicolumn{3}{|c|}{ DME, \% } & & & \multicolumn{2}{|c|}{ WOT, \% } \\
\hline & 100 & 90 & 69 & 48 & 33 & 21 \\
\hline 0 & 29.07 & 26.1 & 25.65 & 22.95 & 20.7 & 19.8 \\
\hline 7 & 26.28 & 23.76 & 23.94 & 22.05 & 20.61 & 20.7 \\
\hline 9 & 23.94 & 24.66 & 24.75 & 22.77 & 20.88 & 19.35 \\
\hline 11 & 23.31 & 24.39 & 25.47 & 22.5 & 21.87 & 20.52 \\
\hline 14 & 22.23 & 24.66 & 26.19 & 24.93 & 22.59 & 20.34 \\
\hline 17 & 21.33 & 21.96 & 24.3 & 24.93 & 21.69 & 20.7 \\
\hline
\end{tabular}

Fig. 20. Efficiency of tested engine in depend of DME share \& engine load, $\mathrm{n}=2500 \mathrm{rpm}$

\section{Conclusion}

Based on the research and analyzes carried out, the following conclusions can be drawn:

1. DME (BioDME) can be used as a component of fuel blend with LPG in certain proportions, as it ensures maintenance of the engine performance level. Too high DME content causes changes in the combustion process, which leads to a deterioration of the energy conversion efficiency of the SI engine

2. At full engine load an additive of DME should be limited to approx. $10 \%$ (by weight). In the partial load range, of $50-70 \%$, its share can be increased to about $17 \%$.

3. The use of the DME additive does not increase the temperature and thermal stresses of the engine compared to feeding only with LPG. The presence of DME in the indicated amounts, does not adversely affect the emission of toxic exhaust gas components

4. Because of the general efficiency of the engine (Fig. 20 ), the range of partial loads is most advantageous because the highest values (LPG-like) are obtained there. This is the most common operating range of the engine.

5. The observed effect of DME share on the combustion velocity requires further investigation taking into account the ignition advance angle correction.

\section{Nomenclature}

CI compression ignition

$\mathrm{CN}$ cetane number

CNG compressed natural gas

DME dimethyl ether
LPG liquified petrolum gas

MFB mass fraction burned

SI spark ignition

\section{Bibliography}

[1] IDA Fact Sheet DME/LPG Blends 2010 v1.

[2] FLEKIEWICZ, M., KUBICA, G., FLEKIEWICZ, B. The analysis of energy conversion efficiency in SI engines for selected gaseous fuels. SAE Technical Paper. 2014, 201401-2692.

[3] FLEKIEWICZ, M., KUBICA, G., The effects of blending dimethyl ether with LPG on the engine operation and its efficiency. Combustion Engines. 2013, 154(3), 86-95.

[4] KUBICA, G. Efektywność konwersji energii w silniku o zapłonie iskrowym zasilanym paliwami gazowymi o obniżonym udziale węgla. Publishing House of the Institute for Sustainable Technologies-National Research Institute in Radom. 2013.

Marek Flekiewicz, DEng. - Faculty of Transport at Silesian University of Technology.

e-mail: Marek.Flekiewicz@polsl.pl

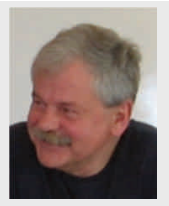

Grzegorz Kubica, DSc., DEng. - Faculty of Transport at Silesian University of Technology. e-mail: Grzegorz.Kubica@polsl.pl
[5] LEE, S., OH, S., CHOI, Y., KANG, K. Effect of n-butane and propane on performance and emission characteristics of an SI engine operated with DME-blended LPG fuel. Fuel. 2011, 90, 1674-1680.

[6] NAKAZONO, T., RAIHAN, K.A., NISHIMURA, A. A study of application DME-LPG blended fuel to gas engine for micro cogeneration (2nd Report, Engine Control). JSME. 2010, 76/763, 397-399.

[7] SORENSON, S.C. Dimethyl ether in diesel engines: Progress and perspectives. J. Eng. Gas Turbines Power. 2001, 123(3), 652-658.

[8] WEIDOU, N., LIJAN, T., DEWEI, F. Rational cognition of DME market in China. Proceedings of $3 r d$ Asian DME conference. 2006, 21-38.

Paweł Marzec, MEng. - Faculty of Transport at Silesian University of Technology.

e-mail:Pawel.Marzec@polsl.pl
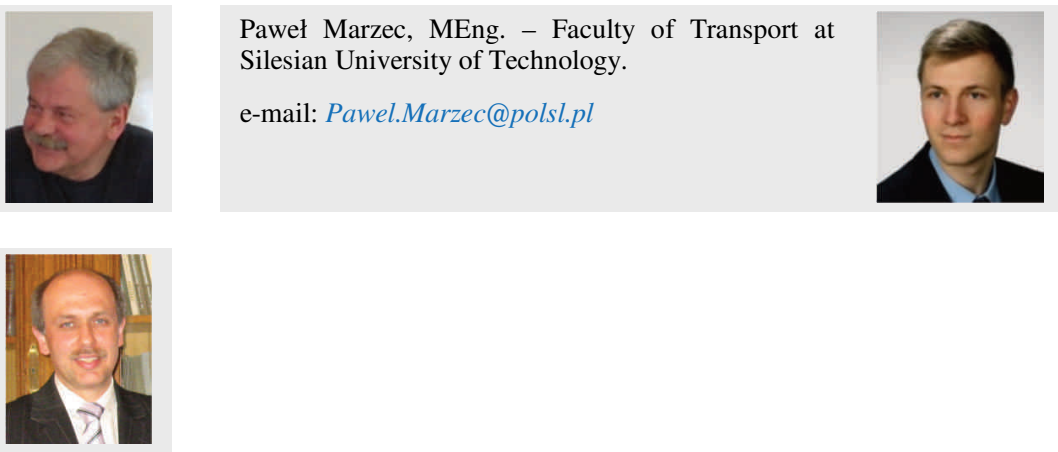